\title{
Author Correction: Low efficiency of large volcanic eruptions in transporting very fine ash into the atmosphere
}

\author{
Mathieu Gouhier ${ }^{1}$, Julia Eychenne ${ }^{1}$, Nourddine Azzaoui ${ }^{2}$, Arnaud Guillin ${ }^{2}$, \\ Mathieu Deslandes ${ }^{3}$, Matthieu Poret $\mathbb{I D}^{4}$, Antonio Costa $\mathbb{D}^{4} \&$ Philippe Husson ${ }^{3}$
}

Correction to: Scientific Reports https://doi.org/10.1038/s41598-019-38595-7, published online 05 February 2019

The Acknowledgements section in this Article is incomplete.

"J.E. was funded by the Research Institute for Development (IRD). We are particularly grateful to Timothy H. Druitt for constructive scientific discussions. We warmly thank A. Folch and one anonymous reviewer for constructive comments."

should read:

"J.E. was funded by the Research Institute for Development (IRD). We are particularly grateful to Timothy H. Druitt for constructive scientific discussions. We warmly thank A. Folch and one anonymous reviewer for constructive comments. We thank the European project EUROVOLC (grant number 731070), A.C. also acknowledges the Italian MIUR project Premiale Ash-RESILIENCE."

(i) Open Access This article is licensed under a Creative Commons Attribution 4.0 International License, which permits use, sharing, adaptation, distribution and reproduction in any medium or format, as long as you give appropriate credit to the original author(s) and the source, provide a link to the Creative Commons license, and indicate if changes were made. The images or other third party material in this article are included in the article's Creative Commons license, unless indicated otherwise in a credit line to the material. If material is not included in the article's Creative Commons license and your intended use is not permitted by statutory regulation or exceeds the permitted use, you will need to obtain permission directly from the copyright holder. To view a copy of this license, visit http://creativecommons.org/licenses/by/4.0/.

(C) The Author(s) 2019

\footnotetext{
${ }^{1}$ Université Clermont Auvergne, CNRS, IRD, OPGC, Laboratoire Magmas et Volcans, F-63000, Clermont-Ferrand, France. ${ }^{2}$ Laboratoire de Mathématiques Blaise Pascal, UMR 6620 CNRS \& UCA, Aubière, France. ${ }^{3}$ VAAC Toulouse, Météo France, Toulouse, France. ${ }^{4}$ Istituto Nazionale di Geofisica e Vulcanologia, Sezione di Bologna, Bologna, Italy. Correspondence and requests for materials should be addressed to M.G. (email: M.Gouhier@opgc.fr)
} 